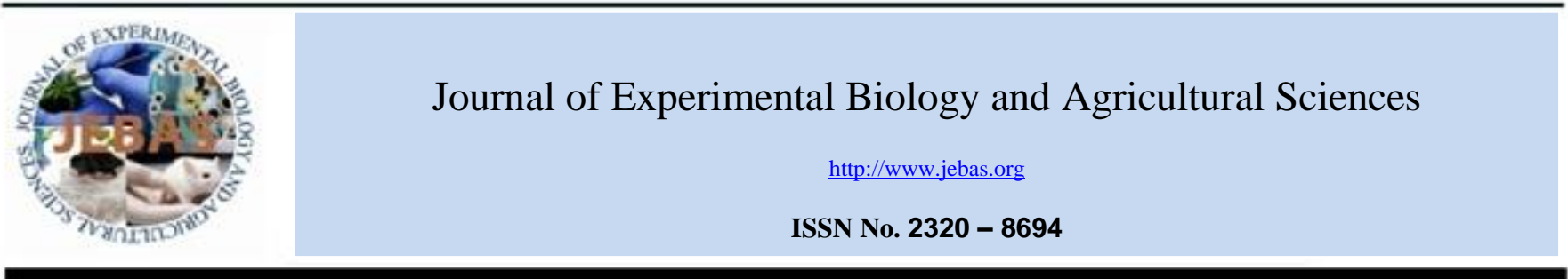

\title{
A HIGHLY HEAVY METAL TOLERANT Fusarium solani WITH EFFICIENT BIOACCUMULATION POTENTIALITY FROM CONTAMINATED SOIL
}

\section{Pravash Mondal, Bejoysekhar Datta, Sujata Chaudhuri *}

Mycology and Plant Pathology Laboratory, Department of Botany, University of Kalyani, Kalyani, West Bengal, India.

Received - September 30, 2019; Revision - November 16, 2019; Accepted -December 12, 2019

Available Online - December 25, 2019

DOI: http://dx.doi.org/10.18006/2019.7(6).579.586

\section{KEYWORDS \\ Fusarium solani \\ Heavy metals \\ Tolerance index \\ Bioaccumulation \\ Bioremediation}

\begin{abstract}
Bioremediation of toxic metal contaminated soil and wastewater by filamentous soil fungi is a promising approach. In the present study, tolerance and bioaccumulation ability of Fusarium solani were tested for four heavy metals viz. cadmium $(\mathrm{Cd})$, lead $(\mathrm{Pb})$, nickel $(\mathrm{Ni})$ and chromium $(\mathrm{Cr})$. The fungus, isolated from textile-dye contaminated soil, was cultured on potato dextrose agar (PDA) and potato dextrose broth (PDB) supplemented with different metals to investigate metal tolerance and removal efficiency respectively. After 10 days of fungal growth in metal containing PDB, the remaining metal amount was evaluated by atomic absorption spectrophotometer (AAS).Minimum inhibitory concentrations of heavy metals up to which the isolate could grow were 2100, 3600, 2700 and $3900 \mathrm{ppm}$ for $\mathrm{Cd}, \mathrm{Pb}, \mathrm{Ni}$ and $\mathrm{Cr}$ respectively. The highest tolerance index was recorded against $\mathrm{Cr}$ (1.07), followed by $\mathrm{Pb}(1.02), \mathrm{Ni}(0.77)$ and $\mathrm{Cd}(0.66)$. Up to certain concentration, both $\mathrm{Cr}$ and $\mathrm{Pb}$ showed stimulatory effect on the growth of the isolate. Maximum bioaccumulation was observed for $\mathrm{Cr}$ (86.5\%) followed by $\mathrm{Pb}(85.5 \%)>\mathrm{Ni}(75.3 \%)>\mathrm{Cd}(68.6 \%)$. The fungal isolate showed maximum growth, tolerance and bioaccumulation at $\mathrm{pH} 6$ and $28^{\circ} \mathrm{C}$ temperature. FTIR spectra of dried biomass grown with or without heavy metals showed stretching vibration at $4000-400 \mathrm{~cm}^{-1}$ which revealed the interaction between heavy metals and functional groups of biomass. Thus, it can be concluded that this fungal isolate has a potential of being a suitable for efficient heavy metal bioaccumulation and bioremediation of polluted soil and waste water.
\end{abstract}

* Corresponding author

E-mail: sujatachaudhuri@gmail.com (Sujata Chaudhuri)

Peer review under responsibility of Journal of Experimental Biology and Agricultural Sciences.

Production and Hosting by Horizon Publisher India [HPI] (http://www.horizonpublisherindia.in/).

All rights reserved.
All the articles published by Journal of Experimental Biology and Agricultural Sciences are licensed under a Creative Commons Attribution-NonCommercial 4.0 International License Based on a work at www.jebas.org.

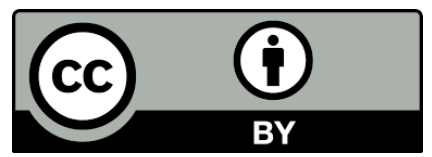




\section{Introduction}

Environmental pollution is a global challenge and among various types of pollution, heavy metals are one of the most hazardous pollutants (Xiezhi et al., 2005). Discharge of these heavy metals into soil and water is a foremost health concern worldwide, which has long-term harmful effects on the ecosystem, since they cannot be broken down to non-toxic forms (Singh et al., 2011). Even at very low concentrations many of them show toxic effects. Cadmium, arsenic, lead, chromium, nickel, copper, mercury, selenium, zinc, silver etc. are cytotoxic, mutagenic and carcinogenic in nature when they enter in the food chain (Salem et al., 2000). Presence of these toxic materials in soil and water affects both flora and fauna, in addition to pollution of groundwater through leaching. Further, contaminated soil can lead to reduction of plant growth, performance and product quality in agriculture. It affects the microbial activity in the ecosystem. It is also harmful to public health and other organisms due to environmental stress (Khosravi et al., 2009; Mohsenzade et al., 2012). Heavy metals are discharged into the environment by sewage and waste materials of paint industry, metal plating, batteries, textile dyeing industry, metallurgy, pesticides, combustion of fossil fuels, released oil ingredients in the soil, ores washing, mining, natural erosion of rocks, coloured material etc. (Vadkertiova \& Slavikova, 2006). Bioremediation is an ecofriendly and encouraging technology which helps in heavy metal removal from polluted water and soil. For survival in heavy metal polluted soil, microorganisms improve and adopt various decontaminating mechanisms such as bioaccumulation, biosorption and biotransformation. These organisms can be exploited either $e x$ situ or in situ for bioremediation (Gadd, 2000; Lim et al., 2003, Malik,. 2004; Lin \& Lin, 2005). Worldwide bioremediation technologies were surveyed by Elekwachi et al. (2014) for addressing the environmental problems.

Generally, for heavy metal tolerance and bioremediation in filamentous fungi two mechanisms i.e. extracellular and intracellular sequestration have been proposed. In extracellular mechanism (biosorption), heavy metals bind to the fungal cell wall without entry into the cell. The fungal cell wall is made up of glucan and chitin, which are negatively charged containing various anionic structures (Maghsoodi et al., 2007). Thus fungi cell wall could bind with heavy cations metals. In the intracellular mechanism, toxic metal ions are either extruded from the cytosol, out of the cell or by metal sequestration into vacuolar compartment by transport proteins (Tawab Abdul \& Maqsood, 2007). In this study, the tolerance of fungal strain Fusarium solani for heavy metals $\mathrm{Cd}, \mathrm{Pb}, \mathrm{Ni}$ and $\mathrm{Cr}$ was studied. The main objective of the work was to investigate the effect of metal concentration, $\mathrm{pH}$ and temperature, at which optimum metal tolerance was found. Further, tolerance index, minimum inhibitory concentration (MIC) and removal percentage of heavy metals were also investigated.

\section{Materials and Methods}

\subsection{Heavy metal stock solutions preparation}

Stock solutions of heavy metals with 10000 ppm concentration $\mathrm{Cd}(\mathrm{II}), \mathrm{Pb}(\mathrm{II}), \mathrm{Ni}(\mathrm{II})$ and $\mathrm{Cr}(\mathrm{III})$ were prepared by dissolving analytical reagent grade salts of $\mathrm{CdCl}_{2} . \mathrm{H}_{2} \mathrm{O}, \mathrm{Pb}\left(\mathrm{NO}_{3}\right)_{2}$, $\mathrm{NiCl}_{2} \cdot 6 \mathrm{H}_{2} \mathrm{O}, \mathrm{Cr}\left(\mathrm{NO}_{3}\right)_{3}$ in milli-Q water. From the metal stock solution, further concentrations of each metal were prepared.

\subsection{Soil sample collection}

Soil samples were collected from polluted soil to a depth of $15 \mathrm{~cm}$ from dumping areas contaminated with effluent of textile dyeing factory at Santipur, Nadia District, West Bengal. Soil was collected in sterilized plastic bag, transported to the laboratory in icebox and stored in refrigerator in $4^{\circ} \mathrm{C}$ for further work within $12 \mathrm{~h}$.

\subsection{Isolation of the Fungal isolate}

Soil sample $(1 \mathrm{~g})$ was suspended in $10 \mathrm{ml}$ of sterile distilled water and further dilutions were made. To isolate $F$. solani, soil dilutions of $10^{-2}, 10^{-3}, 10^{-4}$ and $10^{-5}$ were used to evade over-crowded fungal colonies. Soil suspension of $100 \mu 1$ of each concentration was added to sterile petri plates containing $30 \mathrm{ppm}$ streptomycin, $20 \mathrm{ml}$ of sterile Potato Dextrose Agar (PDA) medium.Three replications were maintained for each treatment. The culture plates were incubated at $28 \pm 1^{\circ} \mathrm{C}$ in the dark and monitored everyday up to 7 days. Each developed fungal colony was sub-cultured to obtain pure cultures (Ezzouhri et al., 2009; Kumar et al., 2015).

\subsection{Identification of the Fungal isolate}

Isolated $F$. solani species identification was carried out by the method of Booth (1977) and Smith(2007) based on colony characteristic on PDA (colonial morphology, color, appearance) and microscopic characteristics (septation of mycelium, shape diameter and texture of reproductive structure i.e. conidia).

Molecular identification of the fungal isolate was done by sequencing of $18 \mathrm{~S}$ rDNA. Genomic DNA was isolated by CTAB method (Datta \& Chaudhuri, 2017). For rDNA amplification ITS (ITS4, ITS5)) Forward: 5'-TCCTCCGCTTATTGATATGC-3' and Reverse 5'-GAAGTAAAAGTCGTAACAAGG-3' primers (Schoch et al., 2012) were used. To perform PCR, a total reaction volume of $50 \mu \mathrm{l}$ was used which contained $0.25 \mathrm{mM}$ of each dNTP, $1.5 \mathrm{mM} \mathrm{MgCl} 2$, 1x Taq buffer, $1.5 \mathrm{U}$ of Taq DNA Polymerase, $0.2 \mu \mathrm{M}$ of each primer, and $200 \mathrm{ng}$ of template DNA. Condition for amplification of the PCR cycling was $95^{\circ} \mathrm{C}$ for 10 minute; 35 cycles at $95^{\circ} \mathrm{C}$ for 15 second, $52^{\circ} \mathrm{C}$ for 30 second, and at $72^{\circ} \mathrm{C}$ for 1.5 second; $72^{\circ} \mathrm{C}$ for 7 minute and hold at $4^{\circ} \mathrm{C}$ (Schoch et al., 2012). 


\subsection{Minimum inhibitory concentration (MIC)}

Potato dextrose agar (PDA) culture medium was supplemented with increasing heavy metal concentrations viz. 200, 400, 600, $800,1000,1500,2500,3000,3500$ and $4000 \mathrm{ppm}$. The culture plates were inoculated with $5 \mathrm{~mm}$ inoculum disks from pure young cultures. Fungal growth on metal containing culture plates were observed after 10 days of inoculation. The lowest concentration of heavy metal which prevented visible fungal growth was considered as minimum inhibitory concentration (Fazli et al., 2015).

\subsection{Tolerance Index of Fungi}

The tolerance index (TI) was defined as the division of fungal growth in heavy metal containing plates with fungal growth in without metal plates i.e. control plates. The higher TI value indicated greater resistance. Five mm disks of fungal isolate from 10 day old pure cultures were inoculated into petri plates containing PDA supplemented with $200 \mathrm{ppm}$ of $\mathrm{Cd}, \mathrm{Pb}, \mathrm{Ni}$ and $\mathrm{Cr}$, separately, a combination of two metals of $100 \mathrm{ppm}$ each as well as in mixture of all four metals $(4 \times 50 \mathrm{ppm})$.Parallel cultures, without metal were maintained as a control. Three replications were maintained for each treatment. The inoculated plates were then incubated at $28 \pm 1^{\circ} \mathrm{C}$ for 7 days. The radial growth of the fungal mycelia on culture plate from four measurements (in millimetres) that passed through the centre was evaluated. The mean of evaluated diameter measurements for each plate on the $7^{\text {th }}$ day was recorded.

\subsection{Bioaccumulation of heavy metals}

For the determination of bioaccumulation ability of the fungal isolate, three $5 \mathrm{~mm}$ inoculums disks from 10day old mycelia culture, was inoculated into $150 \mathrm{ml}$ conical flask containing $50 \mathrm{ml}$ potato dextrose broth (PDB) and 20, 30, 40 and 50 ppmof each heavy metal, in separate conical flasks. Initial concentration of heavy metals in each conical flask was tested by Atomic Absorption Spectrophotometer (AAS) before fungal inoculation. The $\mathrm{pH}$ was adjusted to 6 at which the optimum fungal growth was found. In controls PDB medium with 20 ppm of each metal in conical flasks, without fungal inoculum were maintained. All the flasks were incubated on a rotary shaker at $28 \pm 1^{\circ} \mathrm{C}$ in dark. After 10 days of incubation, the flasks containing fungal mycelia were filtered through filter paper (Whatman No.42). For determination of total metal concentration, the filtrate was subjected to acid digestion with $\mathrm{HNO}_{3}$ and $\mathrm{HCl}$ in 1:3 ratio,on a hot plate, until the red nitrous fumes production stopped and the liquid becomes colorless.The cooled liquid was diluted with milli-Q water and filtered through Whatman's No.1 filter paper (Uddin et al., 2016). Heavy metal content was analyzed using AAS (Juwarkar, 1988). The residual fungal mycelia were rinsed three times with milli-Q water and dried in hot air oven at $70^{\circ} \mathrm{C}$ until the weight became constant. The dried fungal biomass was defined as dry biomass and weighed $(\mathrm{g})$. The percentage of heavy metal uptake by the fungal mycelia was calculated by using the following equation (Mohsenzadeh \& Shahrokhi, 2014; de Lima et al., 2013)

$$
q=\frac{(\mathrm{Ci}-\mathrm{Cf})}{\mathrm{Ci}} \times 100
$$

where, $\mathrm{q}$ is the metal uptake percentage (\%); $\mathrm{Ci}(\mathrm{ppm})$ is the initial metal concentration; $\mathrm{Cf}(\mathrm{ppm})$ is the final metalconcentration.

The effect of bioaccumulation of heavy metals at 20ppm of each metal by F.solani at different $\mathrm{pH}$ and temperature was also studied.

\subsection{FTIR analysis}

To analyse the functional groups on the dried fungal biomass surface before and after metal biosorption, Fourier transform infrared spectra (FTIR) method was used. The dried biomass was treated with $\mathrm{KBr}$ pellets; spectra were recorded at the range of $4,000-400 \mathrm{~cm}^{-1}$ using a $\mathrm{KBr}$ window with a spectrometer. In order to find out the differences between the biomass treated with metals and biomass without metal were also analysed with FTIR.

\section{Results and Discussion}

Based on colonial morphology, appearance and color of fungal mycelia on culture plate and microscopic characteristics viz. mycelia septation, size, shape, diameter, texture and septation of reproductive structure i.e. conidia and also on18S rDNA sequencing, the fungal isolate was identified as F.solani. The $18 \mathrm{~S}$ rDNA fragment was submitted to the NCBI gene bank and the accession number was MK829000.

\subsection{Minimum inhibitory concentration (MIC)}

It was found that the resistance level of F.solani was different for the different tested metals (Figure 1).The order of concentrations of heavy metals up to which mycelia of $F$. solani grown was $\mathrm{Cr}$ $(3900 \mathrm{ppm})>\mathrm{Pb}(3600 \mathrm{ppm})>\mathrm{Ni}(2700 \mathrm{ppm})$. These results revealed that $F$. solani showed maximum resistant to Chromium; this higher MIC value indicated more resistance to that metal. Cadmium showed highest toxic effect among all four metals on cellular metabolic activity which directly affected mycelial growth as a result it showed lowest MIC value. The MIC values of the fungus evaluated in the present study are higher than those reported by Parameswari et al. (2010) and Zafar et al. (2007). However, MIC values reported by Ahmad et al. (2005) are in agreement with the findings of present study.

\subsection{Tolerance Index of Fungi}

Heavy metal tolerance index of F.solani represented by Figure 2. Tolerance index of F.solani in heavy metals (both in single and 
multi-metal culture) ranged from 0.57 to 1.07 at 200 ppm concentration. Higher TI value indicates higher resistance to the particular metal ion. In single metal culture, $\mathrm{Cr}$ containing plates showed maximum tolerance (1.07), followed by $\mathrm{Pb}$ (1.02), $\mathrm{Ni}(0.77)$ and $\mathrm{Cd}$ (0.66). In multi-metal cultures, it showed greater growth than on control plate and the T.I. value was 1.07. Akhtar et al. (2013) also reported that Aspergillus flavus (SF-4) showed $\geq 1$ T.I value for $\mathrm{Ni}$ and $\mathrm{Cu}$. In bi-metal culture $\mathrm{Cd}+\mathrm{Cr}$ (100ppm $+100 \mathrm{ppm}$ ) containing culture plate showed highest growth i.e. maximum tolerance $(0.82)$ followed by $\mathrm{Cd}+\mathrm{Pb}(0.76)$ and $\mathrm{Cd}+\mathrm{Ni}(0.57)$. F.solani showed not only higher tolerance to $\mathrm{Pb}$ and $\mathrm{Cr}$ but its growth was stimulated in presence of these two (Figure 3). According to Roane \& Pepper (2000) the distinction in degree of resistance to different metals was undoubtedly due to the potential variation in the resistance mechanism. It was reported by PerfusBarbeoch et al. (2002) that $\mathrm{Cd}$ inhibition to physiological processes such as growth and photosynthesis at less than $2 \mathrm{ppm}$ concentration had also been observed in microorganisms.

\subsection{Bioaccumulation of Heavy Metals}

In the present study F.solani showed a wide range of diversity in heavy metals bioaccumulation at different concentrations (Figure 4). It was observed that with increasing of heavy metals concentration, the bioaccumulation percentage decreased. At $20 \mathrm{ppm}$ of heavy metals, the isolate showed highest accumulation of $\mathrm{Cr}(86.5 \%)$ followed by $\mathrm{Pb}(85.5 \%), \mathrm{Ni}(75.3 \%)$ and $\mathrm{Cd}(68.6 \%)$. Bioaccumulation percentages of heavy metals were significantly decreased with increase of metal concentrations (Table 1). In $\mathrm{Cr}$ treatment, weight of fungal biomass was greater than the biomass in untreated PDB after 10 days of incubation period. While lower concentrations of $\mathrm{Cr}$ stimulated the fungal growth, its increased concentration resulted in increased toxicity.

Khurshid et al. (2016) reported that $F$. oxysporum showed $80-90 \%$ bioaccumulation of $\mathrm{Cr}$ (IV) at the concentration of $5-350 \mathrm{ppm}$. At higher metal concentrations bioaccumulation efficiency decreased due to saturation of ligands on the fungal cell wall (Rao et al., 2005). Functional groups in fungal cell wall involved in the binding of heavy metals are carboxyl, hydroxyl and phosphate which have high covalent affinity towards metal ions.

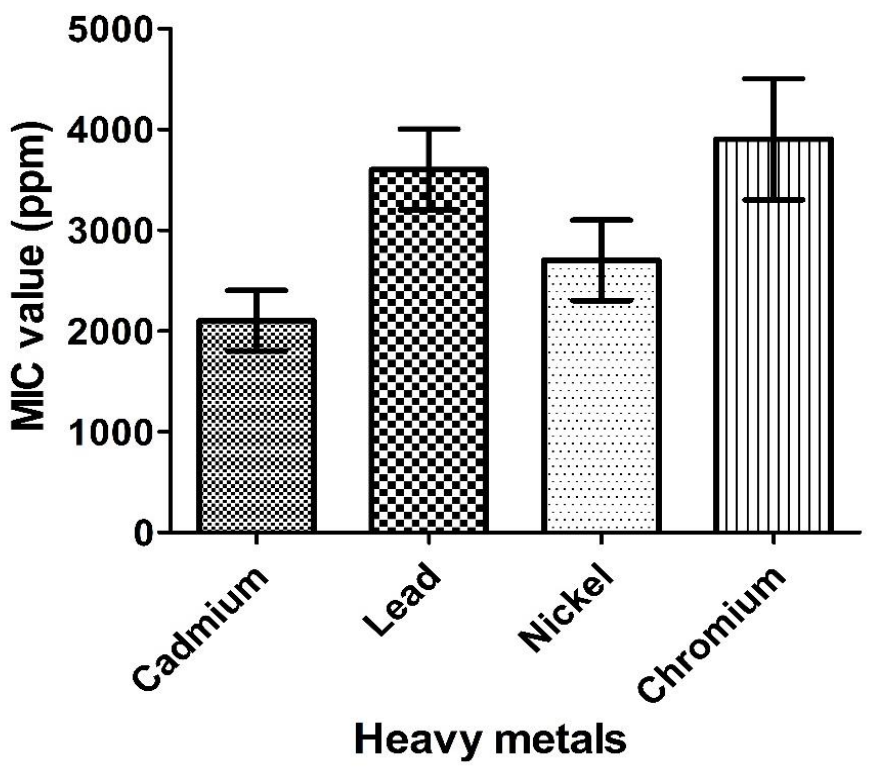

Figure 1 Minimum inhibitory concentrations (MIC) of cadmium, lead, nickel and chromium. Each data is mean of 3 replicates. The line on each bar represent standard deviation.MIC of different metals differ significantly $(\mathrm{P}<0.05)$.

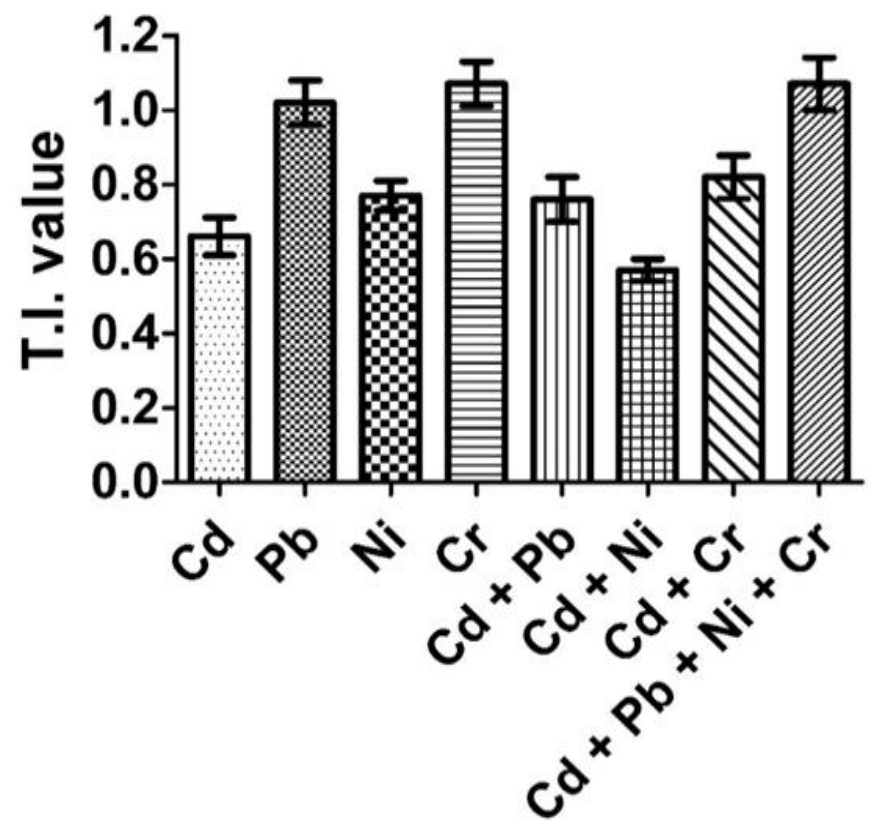

Heavy metals

Figure 2 Tolerance Index of Fusarium solani at $200 \mathrm{ppm}$ (single metal), $2 \times 100 \mathrm{ppm}$ (bi- metals) and $4 \times 50 \mathrm{ppm}$ ( multi-metals). Data of each column is mean of $n=3$. Bar line of each column indicates standard deviation. T.I of different metals or combination of metals were significantly different $(\mathrm{P}<0.05)$ except $\mathrm{Cd}+\mathrm{Ni}$ containing culture. 

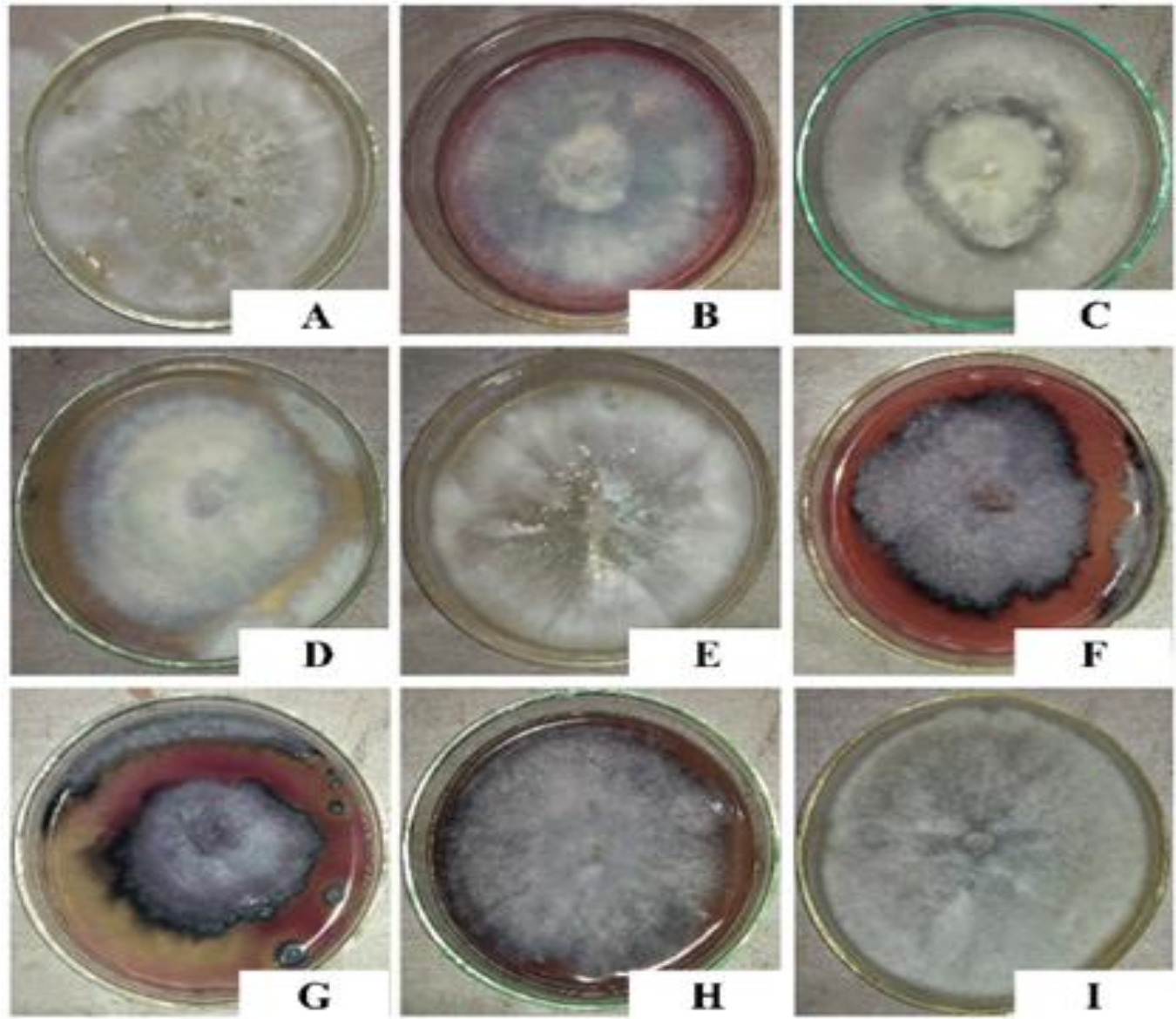

Figure 3 Effect of heavy metals on fungal growth and morphology. A. is control plate (without any metal); B, C, D and E (with $\mathrm{Cd}, \mathrm{Pb}, \mathrm{Ni}$ and $\mathrm{Cr}$ respectively); $\mathrm{F}, \mathrm{G}$ and $\mathrm{H}$ (with $\mathrm{Cd}+\mathrm{Pb}, \mathrm{Cd}+\mathrm{Ni}$ and $\mathrm{Cd}+\mathrm{Cr}$ respectively); $\mathrm{I}$ (with $\mathrm{Cd}+\mathrm{Pb}+\mathrm{Ni}+\mathrm{Cr}$ )

Table 1 Two way ANOVA test for calculation of significance differences in bioaccumulation potentiality by fungal mycelia.

\begin{tabular}{|c|c|c|c|c|}
\hline $\begin{array}{l}\text { Factors effecting } \\
\text { bioaccumulation }\end{array}$ & $\begin{array}{l}\text { Cadmium } \\
\text { S }\end{array}$ & $\begin{array}{l}\text { Lead } \\
\qquad \mathrm{S}\end{array}$ & $\begin{array}{c}\text { Nickel } \\
\text { S }\end{array}$ & $\begin{array}{c}\text { Chromium } \\
\text { S }\end{array}$ \\
\hline $\begin{array}{c}\text { Metal } \\
\text { concentrations } \\
20 \\
30 \\
40 \\
50\end{array}$ & $\begin{array}{c}- \\
\mathrm{ns} \\
\mathrm{ns} \\
*\end{array}$ & $\begin{array}{l}- \\
\mathrm{ns} \\
* * \\
* *\end{array}$ & $\begin{array}{c}- \\
\mathrm{ns} \\
\mathrm{ns} \\
*\end{array}$ & $\begin{array}{c}- \\
\mathrm{ns} \\
* \\
* *\end{array}$ \\
\hline $\begin{array}{c}\mathrm{pH} \text { value } \\
4 \\
5 \\
6 \\
7 \\
8\end{array}$ & $\begin{array}{c}- \\
* * \\
* * * \\
\mathrm{~ns} \\
\mathrm{~ns}\end{array}$ & $\begin{array}{c}- \\
* * \\
* * * \\
* \\
\mathrm{~ns}\end{array}$ & $\begin{array}{l}- \\
* * * \\
* * * \\
* * * \\
\mathrm{~ns}\end{array}$ & $\begin{array}{c}- \\
* \\
* * * \\
\mathrm{~ns} \\
\mathrm{~ns}\end{array}$ \\
\hline $\begin{array}{c}\text { Temperature } \\
18 \\
28 \\
38\end{array}$ & $\begin{array}{l}- \\
* * * \\
* *\end{array}$ & $\begin{array}{c}- \\
* * * \\
* * *\end{array}$ & $\begin{array}{l}- \\
* * * \\
* *\end{array}$ & $\begin{array}{l}- \\
* * * \\
* *\end{array}$ \\
\hline
\end{tabular}

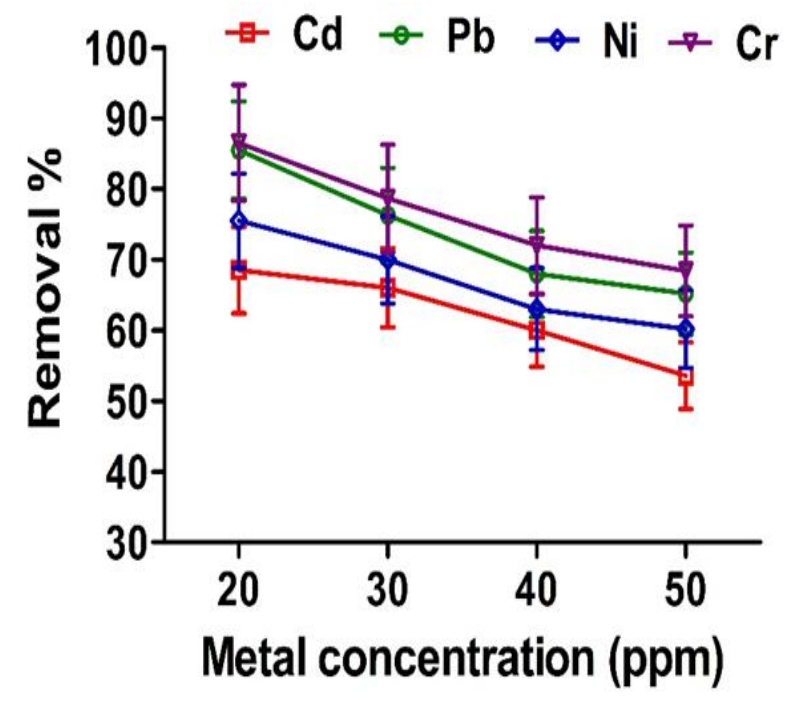

Figure 4 Heavy metal bioaccumulation percentage of Fusarium solani from batch culture of different concentrations of metals at $\mathrm{pH}$ 6. Each data is mean of 3 replicates and the lines of the bars are standard deviation (significance level detail based on Table 1).

Journal of Experimental Biology and Agricultural Sciences http://www.jebas.org 


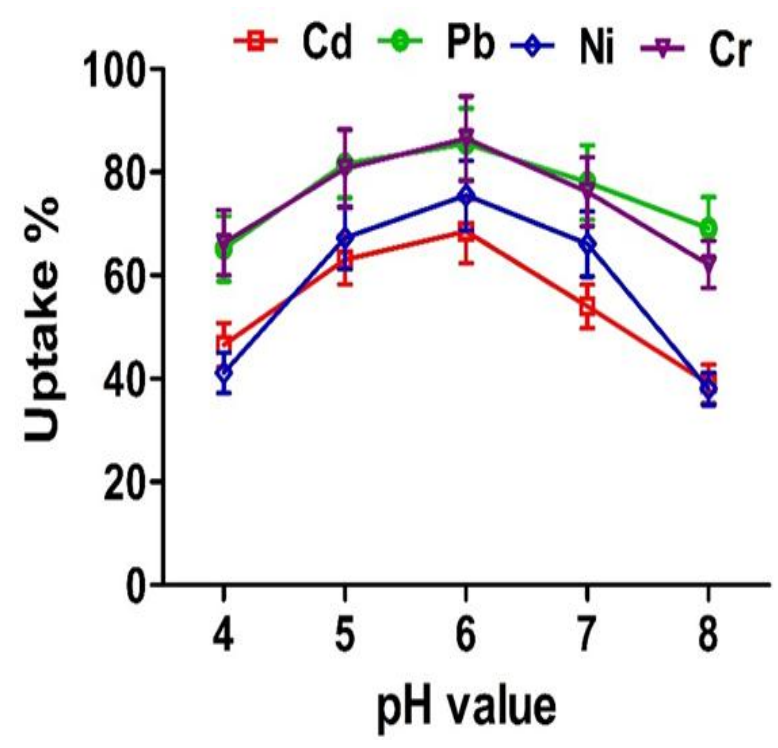

Figure 5 Bioaccumulation percentage of heavy metals at different $\mathrm{pH}$ by Fusarium solani from batch cultures containing $20 \mathrm{ppm}$ of metal. The data are mean of $\mathrm{n}=3$ and the bar lines represent standard deviation (significance level detail based on Table 1).

\subsection{Effect of pH on Heavy Metals bioaccumulation}

Fungal growth is dependent on the $\mathrm{pH}$ of the culture medium Bioaccumulation of heavy metals by F.solani was maximum ( $\mathrm{Cd}$ $=68.6 \%, \mathrm{~Pb}=85.5 \%, \mathrm{Ni}=73.3 \%$ and $\mathrm{Cr}=86.5 \%)$ at $\mathrm{pH} 6.0$ while lower degree of heavy metal accumulation was observed at $\mathrm{pH}$ of 4.0 and 7.0-8.0 (Figure 5). Bioaccumulation at $\mathrm{pH}$ values lower and greater than 6 decreased significantly (Table 1).

At low $\mathrm{pH}$, the surface ligands of fungal cell wall are closely bound with the $\mathrm{H}+$ ions and thus prevent the metal cations to bind. The carboxylic groups of fungal cell wall do not dissociate at low $\mathrm{pH}$ and therefore the metal ions cannot bind (Choudhary \& Sar, 2009). With increase in the $\mathrm{pH}$, the negative charges increase the ligands which favour electrochemical attraction and as a result binding of heavy metal cations increases (Johncy et al., 2010). At high $\mathrm{pH}$ value heavy metals get precipitated causing very low biosorption (Pinoa et al., 2006).

\subsection{Effect of Temperature on Heavy Metals bioaccumulation}

Bioaccumulation of heavy metals observed in F.solani was optimum at $28^{\circ} \mathrm{C}$ for all four metals followed by $38^{\circ} \mathrm{C}$ and $18^{\circ} \mathrm{C}$ (Figure 6). At $28^{\circ} \mathrm{C}$ bioaccumulation of all four heavy metals were $\mathrm{Cr} \quad(86.5 \%)>\mathrm{Pb} \quad(85.5 \%)>\mathrm{Ni} \quad(75.3 \%)>\mathrm{Cd} \quad(68.6 \%)$. Bioaccumulation of metal ions were increased significantly at $18^{\circ} \mathrm{C}$ to $28^{\circ} \mathrm{C}$ and decreased significantly at $28^{\circ} \mathrm{C}$ to $38^{\circ} \mathrm{C}$ temperature

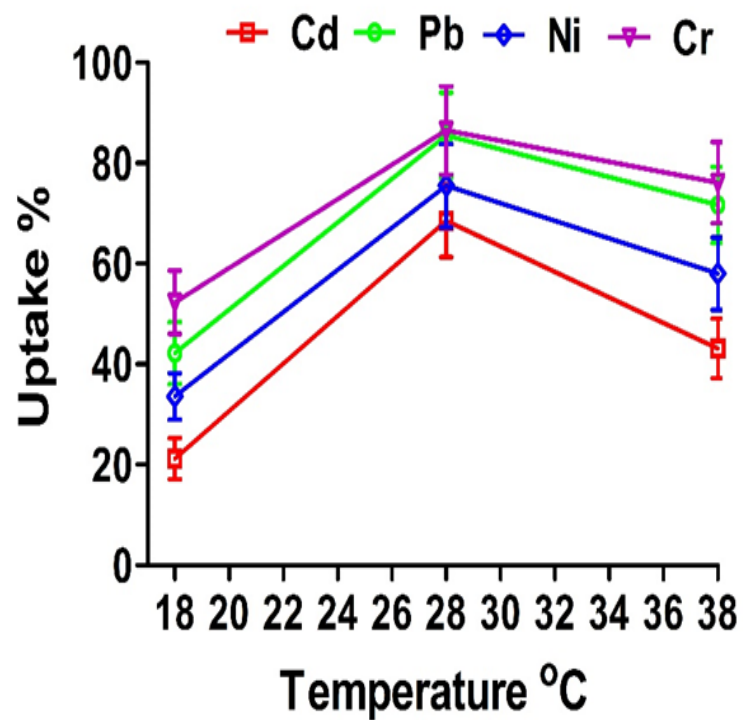

Figure 6 Heavy metal uptake percentages at different temperature by Fusarium solani at $\mathrm{pH} 6$ and $20 \mathrm{ppm}$ metal concentrations from batch culture. Bar lines represent standard deviation which was calculated based on 3 replicates (significance level detail based on Table 1).

(Table 1). Biosorption of heavy metals at the temperature within the range from 25 to $35^{\circ} \mathrm{C}$ affects only to a lesser extent (Veglio \& Beolchini, 1997). At these temperatures, kinetic energy of the solute and surface activity increases as a result of which biosorption of heavy metals also increases (Sag \&Kutsal, 2000). Higher temperature causes physical damage to the biosorbent and reduces biosorption capacity (Srivastava \& Thakur, 2006). Room temperature provides optimum biosorption by a fungus (Vijayaraghavan \& Yeoung, 2008).

3.6 FTIR spectra analysis of fungal biomass with and without heavy metal biosorption

FTIR spectroscopy was used to find out the characteristic functional groups responsible for biosorption of metal ions. The comparative study of the spectra was shown in the figure7. FTIR spectra showed distinct peaks at the range of 4000 to $400 \mathrm{~cm}^{-1}$. Stretching of the broad and strong bands of $-\mathrm{OH}$ and $-\mathrm{NH}$ were attributed at 3500 to $3000 \mathrm{~cm}^{-1}$. Stretching vibrations at 2900 attributed the $\mathrm{C}-\mathrm{H}$, at 1620 to $1590 \mathrm{~cm}^{-1}$ for $\mathrm{C}=\mathrm{O}$, and amide groups, at $1400 \mathrm{~cm}^{-1}$ due to $\mathrm{N}-\mathrm{H}$ of amine groups and at $1025 \mathrm{~cm}^{-}$ ${ }^{1}$ attributed the $\mathrm{C}=\mathrm{O}$ of carboxylic acids and alcohols, at $500 \mathrm{~cm}^{-}$ ${ }^{1}$ stretching of Co-O, similar findings were reported for different metals (Simonescu \& Ferdeş, 2012). Biomass surface of F.solani contained hydroxyl, carboxyl and amine groups. The stretching vibrations at above values indicated the chemical interactions between hydroxyl groups of biomass and metals. 


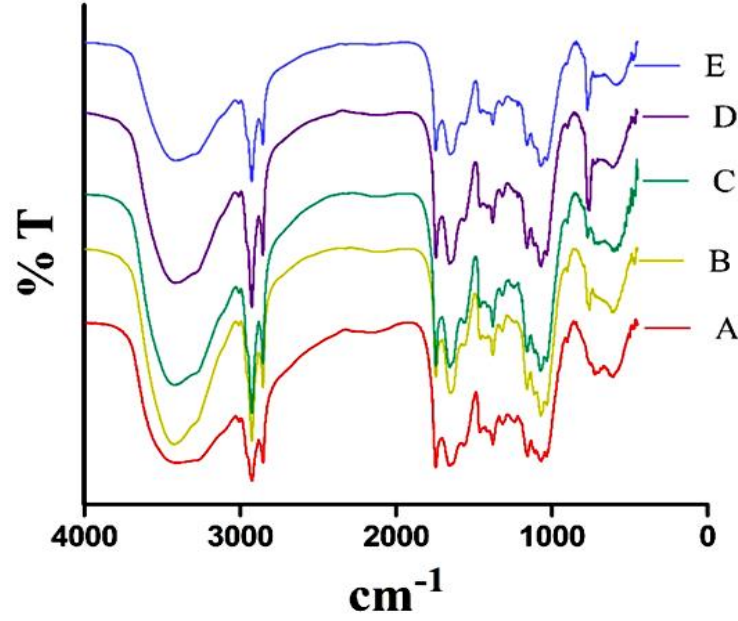

Figure 7 FTIR spectra analysis where $\mathrm{A}=$ control, $\mathrm{B}=$ fungus grown in cadmium, $\mathrm{C}=$ fungus grown in lead, $\mathrm{D}=$ fungus grown in nickel and $\mathrm{E}=$ fungus grown in chromium containing culture media

\section{Conclusion}

It was thus found that F.solani isolated from polluted soil was efficient in accumulating different toxic heavy metals. It could sequester heavy metals from the culture medium to a less toxic level. It could also tolerate very high concentration of heavy metals. Maximum metal tolerance was found for chromium Among the various tested temperature and $\mathrm{pH}$, highest bioaccumulation was reported at $28^{\circ} \mathrm{C}$ and at pH6. FTIR spectrum presents the stretching vibrations at the values ranged from 4000 $400 \mathrm{~cm}^{-1}$ indicated the chemical interactions between heavy metal ions and functional groups of biomass. This fungus needs to exploited for bioremediation of heavy metals from contaminated soil and industrial effluents.

\section{Acknowledgements}

The authors are thankful to Bidhan Chandra Krishi Viswavidyalaya, Mohanpur, for providing Atomic Absorption Spectrophotometer facility and the Department of Chemistry of University of Kalyani for providing FTIR facility. The first author is grateful to UGC for providing Rajiv Gandhi National Fellowship.

\section{Conflict of Interest}

The authors declare that there is no conflict of interest.

\section{References}

Ahmad I, Zafar S, Ahmed F (2005) Heavy metal biosorption potential of Aspergillus sp. and Rhizopussp., isolated from wastewater treated soil. Journal of Applied Sciences and Environmental Management 9:123-126.

Akhtar S, Mahmood-ul-Hassan M, Ahmad R, Suthor V, Yasin M (2013) Metal tolerance potential of filamentous fungi isolated from soils irrigated with untreated municipal effluent. Soil Environment 32:55-62.

Booth C (1977) Fusarium: a Laboratory Guide to the Identifications of the Major Species. CMI, Kew U.K.

Choudhary S, Sar P (2009) Characterization of a metal resistant Pseudomonas sp. isolated from uranimum mine for its potential in heavy metal (Ni2+, $\mathrm{Co} 2+, \mathrm{Cu} 2+$, and $\mathrm{Cd} 2+)$ sequestration. Bioresource Technology 100: 2482-2492.

Datta HK, Chaudhuri S (2017) Bioactive polysaccharides from wild mushroom, coprinosis sp. Journal of Plant Development Sciences 9:761-769

de Lima M, Franco L, de SouzaP, do Nascimento A, da Silva C, Maia R, Rolim H, Takaki G, (2013) Cadmium tolerance and removal from Cunninghamellaelegans related to the polyphosphate metabolism. International journal of molecular sciences 14:7180-7192.

Elekwachi CO, Andresen J, Hodgman TC (2014) Global use of bioremediation technologies for decontamination of ecosystems. Journal of Bioremediation \& Biodegradation 5:1-9.

Ezzouhri L, Castro E, Moya M, Espinola F, Lairini K (2009) Heavy metal tolerance of filamentous fungi isolated from polluted sites in Tangier, Morocco. African Journal of Microbiology Research 3:35-48.

Fazli MM, Soleimani N, Mehrasbi M, Darabian S, Mohammadi J, Ramazani A (2015) Highly cadmium tolerant fungi: their tolerance and removal potential. Journal of Environmental Health Science and Engineering 13:19.

Gadd GM (2000) Bioremedial potential of microbial mechanisms of metal mobilization and immobilization. Current Opinion in Biotechnology11:271-279.

Johncy MR, Hemambika B,Hemapriya J, Rajesh KV (2010) Comparative assessment of heavy metal removal by immobilized and dead bacterial cells: A biosorption approach. African Journal of Environmental Science and Technology 04: 77-83.

Juwarkar A (1988) Bioaccumulation of Zinc by Penicilliumsp. Current Science 57:251-252.

Khosravi F, Savaghebi GH, Farah Bakhsh H (2009) Effect of Potassium chloride on Cd uptake by colza in a polluted soil. Journal of Water and Soil (Agricultural Sciences and Technology) 23:2 8-35. 
Khurshid S, Shoaib A, Javaid A, Abid K (2016) Bioaccumulation of chromium by Fusariumoxysporum. Science Asia 42:92-98.

Kumar PR, Hemanth G, Niharika PS, Kolli SK (2015) Isolation and identification of soil mycoflora in agricultural fields at Tekkali Mandal in Srikakulam District. International Journal of Advances in Pharmacy, Biology and Chemistry 4:484-490.

Lim PE, Mak KY, Mohamed N, Noor AM (2003) Removal and speciation of heavy metals along the treatment path of wastewater in subsurface-flow constructed wetlands. Water Science and Technology 48:307-313.

Lin CC, Lin HL (2005) Remediation of soil contaminated with the heavy metal $(\mathrm{Cd} 2+)$. Journal of Hazardous Materials122:7-15.

Maghsoodi V, Razavi J, Yaghmaei S (2007) Production of Chitosan by submerged fermentation from Aspergillus niger. Scientia IranicaTransaction C, Chemistry, Chemical Engineering16 (2):180-184.

Malik A (2004) Metal bioremediation through growing cells Environment International 30:261-278.

Mohsenzade F, Chehregani A, Akbari M (2012) Evaluation of oil removal efficiency and enzymatic activity in some fungal strains for bioremediation of petroleum-polluted soils. Iranian Journal of Environmental Health Science \& Engineering 9:26-34.

Mohsenzadeh F, Shahrokhi F (2014) Biological removing of Cadmium from contaminated media by fungal biomass of Trichoderma species. Journal of Environmental Health Science and Engineering 12:102.

Parameswari E, Lakshmanan A, ThilagavathiT (2010) Biosorption and metal tolerance potential of filamentous fungi isolated from metal polluted ecosystem. Electronic Journal of Environment and Agricultural Food Chemistry 9: 664-671.

Perfus-Barbeoch L, Leonhardt N, Vavasseur A, Forestier C (2002) Heavy metal toxicity: cadmium permeates through calcium channels and disturbs the plant water status. Plant Journal 32: 539-548.

Pinoa GH, de Mesquitaa LMS, Torema ML, Pinto GAS (2006) Biosorption of Heavy Metals by Powder of Green Coconut Shell. Separation Science and Technology 41:3141-3153.

Rao KR, Rashmi K, Latha JNL, Mohan PM (2005) Bioremediation of toxic metal ions using biomass of Aspergillus fumigatus from fermentative waste. Indian Journal of Biotechnology 4:139-143.

Roane TM, Pepper (2000) Lead resistance to two bacterial isolates from heavy metals contaminated soils. Microbial Ecology 37:218-224.
Sag Y, Kutsal T (2000) Determination of the biosorption activation energies of heavy metal ions on Zoogloea ramigera and Rhizopus arrhizus. ProcessBiochemistry35: 801-807.

Salem HM, Eweida EA, Farag A (2000) Heavy metals in drinking water and their environmental impact on human health. In: Proceedings of the International Conference for Environmental Hazards Mitigation (ICEHM 2000); Cairo University: Giza, Egypt Pp. 542-556.

Schoch CL, Seifert KA, Huhndorf S, Robert V, Spouge JL, Levesque CA, Chen W, Bolchacova E, Voig K, Crous PW, Miller AN (2012) Nuclear ribosomal internal transcribed spacer (ITS) region as a universal DNA barcode marker for Fungi. Proceedings of the National Academy of Sciences 109: 6241-6246.

Simonescu CM, Ferdeş M (2012) Fungal Biomass for $\mathrm{Cu}$ (II) Uptake from Aqueous Systems. Polish Journal of Environmental Studies 21: 1831-1839.

Singh R, Gautam N, Mishra A, Gupta R (2011) Heavy metals and living systems: An overview.Indian Journal of Pharmacology 43:246.

Smith SN (2007) An overview of ecological and habitat aspects in the genus Fusarium with special emphasis on the soil-borne pathogenic forms. Plant Pathology Bulletin 16:97-120.

Srivastava S, Thakur IS (2006)Biosorption potency of Aspergillusniger for removal of chromium (VI). Current Microbiology 153:232-237.

Tawab Abdul IK, Maqsood ZT (2007) Critical behaviour of Iron (III) with a typical catecholatesiderophore. Scientia Iranica14:106-111.

Uddin AH, Khalid RS, Alaama M, Abdualkader AM, Kasmuri A, Abbas SA (2016) Comparative study of three digestion methods for elemental analysis in traditional medicine products using atomic absorption spectrometry. Journal of Analytical Science and Technology 7:6.

Vadkertiova R, Slavikova E (2006) Metal tolerance of yeasts isolated from water. Journal of Basic Microbiology 146:145-152.

Veglio F, Beolcini F (1997) Removal of metals by biosorption: a review. Hydrometallurgy 44: 301-316.

Vijayaraghavan K, Yeoung SY (2008) Bacterial biosorbents and biosorption. Biotechnology Advances 26: 266-291.

Xiezhi Y, Jieming C, Ming HM (2005) Earthworm-mycorrhiza interaction on Cd uptake and growth of ryegrass. Soil Biology and Biochemistry37:195-201.

Zafar S, Aqil F, Ahmad I (2007) Metal tolerance and biosorption potential of filamentous fungi isolated from metal contaminated agricultural soil. Bioresource Technology98: 2557-2561. 